\title{
DESET LET IZHAJANJA \\ BILTENA SLOVENSKE VOJSKE - NOVIM IZZIVOM NAPROTI
}

\author{
TEN YEARS OF THE \\ SLOVENIAN ARMED FORCES BULLETIN - \\ TOWARDS NEW CHALLENGES
}

Povzetek Desetletno obdobje izhajanja Biltena Slovenske vojske (Bilten SV) je priložnost za analizo prehojene poti, pa tudi za pogled v prihodnost. V članku so predstavljeni kvantitativni kazalci uspešnosti izhajanja publikacije: pregled izdanih številk, število prispevkov, število natisnjenih strani in obravnavanih vprašanj z različnih področij delovanja Slovenske vojske in širšega obrambnega sistema ter število avtorjev. Več kot 150 avtorjev je skupaj oblikovalo skoraj 200 predvsem strokovnih člankov. Na začetku leta 2008 je bil oblikovan novi uredniški odbor, že sedmi po vrsti, ki si je zastavil nekaj smelih ciljev, ki jih predstavljamo v nadaljevanju. Seveda pa so glavni izzivi povezani s ciljem uredniške politike, da se v razvrstitvi strokovnih publikacij Bilten SV uvrsti v višji razred, da se povečata strokovnost in število znanstvenih prispevkov, da tako postane ogledalo strokovnosti in profesionalnosti naše vojske. Temu izzivu sledijo predstavljena vizija in strategija uredniškega odbora ter predvsem povabilo k širjenju kroga ustvarjalcev in mreže prejemnikov oziroma bralcev.

Ključne Uredniški odbor, uredniška politika, analitični pregled dosedanjih publikacij, besede prihodnji izzivi za Bilten $S V$.

Abstract The tenth anniversary of the Slovenian Armed Forces' Bulletin (in the further text: SAF Bulletin) provides an opportunity to make an in-depth analysis of the past and a view to the future. The article presents analytical indicators of the past period and achievements in terms of the number of issues, printed pages and topics covering various areas of Slovenian Armed Forces' operations and beyond. More than 150 authors have participated in the creation of almost 200 predominantly subject-matter related articles. The beginning of the year 2008 saw the establishment of the new editorial board, the seventh in the row that set some ambitious goals also described in this article. The main challenges are linked with the desire and goal of the SAF 
Bulletin editorial policy to improve its ranking in the classification of professional publications, to upgrade the level of professionalism and to increase the number of scientific articles, thereby reflecting the level of expertise and professionalism of the Slovenian Armed Forces. This challenge is the basis for the presented vision and strategy of the editorial board and, most of all, an invitation to expand the network of authors, subscribers and readers.

\section{Key words Editorial board, editorial policy, analytical overview of past publications, future} challenges for the Slovenian Armed Forces'Bulletin.

Uvod Deseta obletnica Biltena SVje prava priložnostza analizo prehojene poti in prepoznavo izzivov za prihodnost. Članek predstavlja najpomembnejše ugotovitve iz analize njegovega desetletnega izhajanja. Posebej obravnava poslanstvo in nove izzive ter organizacijo in delovanje uredniškega odbora. Na podlagi spoznanj in pridobljenih izkušenj so opredeljeni cilji in vizija za nadaljnje delovanje ter doseganje osrednjega cilja, to je prehoda iz četrte v tretjo skupino strokovnih publikacij. Namen članka je predstaviti desetletno izdajanje in nadgradnjo dosedanjih izkušenj pri snovanju Biltena za doseganje uredniških ciljev v prihodnosti, iskanje možnosti za širjenje kroga piscev in pripravo prispevkov za njihovo izpopolnjevanje ter predvsem širjenje kroga strokovne in kritične javnosti za teme in vprašanja, ki jih objavljamo.

\section{IZDAJATELJSTVO NA MINISTRSTVU ZA OBRAMBO}

Obrambne znanstvene discipline, veščine in delovni procesi se zaradi posebnosti obrambno-vojaškega področja razlikujejo od sorodnih in tistih zunaj obrambne sfere. Poleg tega je zaradi razvejanosti področja, številčno omejenega kroga uporabnikov in strokovne javnosti v posebnem položaju tudi notranja strokovna komunikacija. Zato ministrstva za obrambo vključno z vojaškimi strukturami opravljajo izdajateljsko in založniško dejavnost. Ta je v sodobnih razmerah globalne družbe in mednarodnih vojaških povezav ter zavezništev v posebnem položaju. Pri tem so vprašanja enotnega pristopa, racionalizacije, doseganja ciljev medijske in strokovne podobe organizacije ter ne nazadnje izrabe novih komunikacijskih medijev in metod resen izziv. Zapisano velja tudi za Republiko Slovenijo oziroma Ministrstvo za obrambo (MO) in Slovensko vojsko ${ }^{1}$.

V MO je bil z reorganizacijo leta 2008 narejen korak za vzpostavitev enotne in procesno povezane izdajateljske dejavnosti v Službi za založništvo (pred tem Služba za publicistiko), pri čemer so se ohranili funkcijsko ločeni izdajatelji, kot so: Slovenska

\footnotetext{
Organiziranje in delovanje založniške dejavnosti v MO je opredeljeno v Pravilniku o založniški in filmski dejavnosti v MO RS (št. dok. 811-11-7/2005-34 z dne 24. 7. 2006). Po pravilniku založniška dejavnost obsega načrtovanje, pripravo in izdajanje vojaškostrokovne in druge literature v tiskani in elektronski obliki ter namizno založništvo.
} 
vojska $^{2}$, Uprava Republike Slovenije za zaščito in reševanje, Obveščevalnovarnostna služba ter organizacijske enote upravnega dela MO. Kljub temu je ta dejavnost $\mathrm{v}$ nekaterih pogledih še vedno procesno razdeljena ali razdrobljena, predvsem pri izdajanju informativnih in periodičnih publikacij, kot so bilteni in zborniki, pa tudi pri pripravi in izdajanju vojaškostrokovne literature s področja znanstvenoraziskovalne dejavnosti ${ }^{3}$. Razdrobljenost se kaže tudi v tem, da enovito vodenje kot pomembna sestavina učinkovite medijske in javne podobe obrambnega sektorja ter njegovih organizacijskih enot ni vzpostavljeno. Tudi procesi, povezani z organizacijo tiskanja, niso povsem usklajeni, saj potekajo v dveh organizacijskih enotah. K temu lahko dodamo še dve vrsti pristopov k izdajateljski dejavnosti. Prvi poteka prek pristojne Službe za založništvo in s sodelovanjem Sektorja za naročila Direktorata za logistiko, drugi pa mimo pristojnih služb, z neposredno oddajo del zunanjim izvajalcem. V MO poleg revije Slovenska vojska, ki namenja pomemben del svoje vsebine vojaškostrokovnim temam, izhaja še Bilten SV. Vojaškostrokovna publikacija Vojstvo, ki je izhajala pred leti, formalno ni ukinjena, vendar ne izhaja. V PDRIU že deveto leto izhaja revija Vojaška zgodovina, ki uvaja nove pristope, predvsem pa se odpira tudi v mednarodni prostor, ne samo v slovenskega. Tako zagotavlja bolj prepoznavno zastopanje vojaškozgodovinske stroke. PDRIU izdaja tudi Vojaškošolski zbornik. Razmejitev ali bolje uskladitev vsebinskih področij, ki jih pokrivajo posamezne publikacije MO, ni dokončno opravljena, saj manjka ustrezen krovni akt o izdajateljski politiki ali strategiji. To na eni strani omogoča proste roke uredniškim odborom pri določanju ciljev in snovanju posameznih publikacij, na drugi pa posamezne publikacije zaradi tega ne morejo doseči višje strokovne ravni ali se izogniti tematskemu oziroma vsebinskemu podvajanju. Tehnično se posamezne izdaje usklajujejo z letnimi in dvoletnimi načrti izdelave literature, ki jih odobri minister za obrambo. Kako obsežna in pomembna je izdajateljska dejavnost v MO, dokazuje letni načrt publikacij za leto 2008, ki predvideva več kot 160 različnih publikacij v obsegu skoraj 2000 avtorskih pol in z nekaj več kot 1.050 .000 tiskanimi listi ter finančnim proračunom 857.000 evrov. K temu SV prispeva skoraj 100 različnih publikacij. V te načrte do zdaj večinoma niso bile vključene promocijske publikacije, kot so glasila poveljstev, enot, operacij in misij, pa tudi drugo promocijsko gradivo (zgibanke, mape, predstavitveni CD idr.).

Z opisanim pa seznam posebnosti ni končan. Navodilo za pripravo in izdajanje periodičnih publikacij SV iz leta 2007 (Navodilo 2007: 4-6) v členih od 8 do 12 določa posebnosti $\mathrm{v}$ organiziranju in sestavi organov publikacij, pristojnostih notranjih organizacijskih enot pri opravljanju nalog založništva in recenzijah. Ena temeljnih posebnosti so položaj in določitev (z odredbo) glavnih urednikov

\footnotetext{
Za izdajatelja in založnika je po Navodilu za pripravo in izdajanje periodičnih publikacij Slovenske vojske določen PDRIU (Navodilo 2007: 5. in 10. člen). PDRIU je po Pravilniku o založniški in filmski dejavnosti v MO iz leta 2006 znotraj SV pristojen za izdajanje doktrin, navodil, metod in meril, učno-izobraževalne literature ter periodičnih publikacij.

3 V Pravilniku o založniški in filmski dejavnosti v MO RS publiciranje s področja znanstvenoraziskovalne dejavnosti ni omenjeno, prav tako ne promocijsko gradivo različnih služb v MO in predvsem promocijsko gradivo poveljstev in enot, operacij ter misij SV.
} 
in uredniških odborov ter struktura članstva $\mathrm{v}$ uredniških odborih ${ }^{4}$, ki sama po sebi kliče na »samocenzuro« ali »cenzuro po hierarhiji«. Takšne rešitve kažejo, da so te publikacije zaprte $\mathrm{v}$ notranji krog organizacije in $\mathrm{v}$ posebnem odnosu do izdajatelja. Po eni strani je to lahko ovira za odprtost in dostop do širše strokovne in znanstvene sfere, pa tudi tujine. Po drugi strani pa postavlja pod vprašaj mehanizem odgovornosti in njeno uveljavljanje glede na to, da gre za prekrivanje funkcijske službene odgovornosti z odgovornostjo v uredniškem odboru. V podobnem položaju je vprašanje sprejemanja uredniške politike, za katero so po Navodilu pristojni uredniški odbori. Ker ni programskih svetov publikacij ${ }^{5}$, se postavljata vprašanji razmerja med založnikom in uredniškim odborom ter potrditve uredniške politike oziroma pridobitve usmeritev zanjo. Tretjo posebnost smo že delno opisali, povezana pa je z odnosom in razmerjem uredniškega odbora do notranjih organizacijskih enot v SV in MO, ki so funkcijsko pristojne za letno načrtovanje publikacij, finančno zagotovitev ter seveda za zagotovitev postopkov tiskanja in distribucije. Gre za odnos med formalnimi organizacijskimi enotami in neformalnimi, kar nedvomno so uredniški odbori glede na status. Razmislek o navedenih in drugih odprtih vprašanjih, pa tudi o racionalizaciji postopkov izdajateljske in založniške dejavnosti MO, tako kliče po uskladitvi in dodatni ali ponovni prenovi.

\section{DESET LET IZHAJANJA BILTENA SV}

Bilten SV je periodična vojaškostrokovna in informativna publikacija, namenjena izobraževanju ter obveščanju javnosti o dosežkih in izkušnjah s področja vojaških, vojaško-tehničnih in drugih ved (Navodilo 2007: 4. čl.). Iz navedene opredelitve izhaja, da je Bilten SV strokovna publikacija Generalštaba SV, namenjena obveščanju in izobraževanju pripadnikov SV, obveščanju drugih obrambnih struktur in javnosti o vojaškostrokovnih področjih ter predstavljanju znanja in izkušenj tujih oboroženih sil in njihovih izobraževalnih ustanov v slovenskem prostoru. Bilten SV omogoča pripadnikom Slovenske vojske in drugim zaposlenim v MO, da svoje strokovno znanje, spoznanja in izkušnje ter zamisli predstavljajo in širijo. Namenjen je tudi štipendistom ministrstva, da lahko predstavljajo izbrane študijske prispevke ter ugotovitve seminarskih in zaključnih nalog. Bilten je odprt predstavnikom obramboslovne strokovne javnosti za predstavljanje znanstvenih oziroma strokovnih prispevkov s področij, ki jih izbira uredniški odbor. Navedeno kaže na to, da je bila dosedanja programska orientiranost zelo široka. Ugotavljamo tudi, da med Biltenom SV, Vojstvom in Vojaškošolskim zbornikom ni bila opravljena razmejitev programske orientiranosti ter ciljnih področij in javnosti, v katere je usmerjena posamezna publikacija. Če se zapisano bere kot kritika, pa je to na drugi strani vendarle omogočilo preživetje in uveljavitev Biltena SV. Dokončna določitev

\footnotetext{
Za uredniške odbore ni formacije, ki je podlaga vojaške organiziranosti. Dejstvo pa je, da se zaradi položajev, ki jih imajo člani uredništev iz SV oziroma MO, „vojaškemu organiziranju« težko izognemo.

5 Navodilo za pripravo periodičnih publikacij SV pri opredeljevanju organov publikacij v 8. členu pri uredniških odborih omenja le razširjeno sestavo uredniških odborov, katerim glavni uredniki najmanj enkrat na leto poročajo o svojem delu in delu uredniških odborov. Razširjeno sestavo uredniškega odbora Biltena SV sestavljajo načelnik Generalštaba SV, poveljnik sil in poveljnik PDRIU.
} 
in uskladitev programske usmerjenosti različnih periodičnih publikacij MO pa tako ostaja izziv za prihodnje.

V nadaljevanju bomo analitični vpogled ${ }^{6} \mathrm{v}$ dosedanje številke Biltenov SV opravili s pregledom uredniških odborov ter izdanih številk in prispevkov. Posebej bomo analizirali strukturo objavljenih prispevkov po vsebinskih področjih in avtorjih. Iz tabele 1 izhaja, da so v obdobju od 1999 do 2008 uredniški odbor vodili štirje glavni in štirje odgovorni uredniki. Skupaj je bilo vanj vključenih 97 članov, od tega 44 različnih oseb. V opazovanem obdobju je bilo izdanih 23 številk.

\begin{tabular}{|c|c|c|c|c|c|c|}
\hline \multirow{9}{*}{$\begin{array}{r}\text { Tabela 1: } \\
\text { Pregled sestave } \\
\text { uredniških } \\
\text { odborov Biltena } \\
\text { SV v obdobju od } \\
1999 \text { do } 2008^{7} \\
\text { (vključno s } \\
\text { številko 10/Št. 3) }\end{array}$} & $\begin{array}{l}\text { Zap. } \\
\text { št. }\end{array}$ & Glavni urednik & Odgovorni urednik & Obdobje & $\begin{array}{l}\text { Število } \\
\text { izdanih } \\
\text { številk }\end{array}$ & $\begin{array}{l}\text { Skupno } \\
\text { število } \\
\text { članov UO }\end{array}$ \\
\hline & 1 & $\begin{array}{l}\text { generalpodpolkovnik } \\
\text { mag. Iztok Podbregar }\end{array}$ & \multirow{2}{*}{ brigadir mag. Alojz Jehart } & $\begin{array}{c}1 \text { leto } \\
\text { in } 7 \text { mesecev }\end{array}$ & 3 & 14 \\
\hline & 2 & \multirow{2}{*}{$\begin{array}{l}\text { brigadir } \\
\text { Ladislav Lipič }\end{array}$} & & 5 mesecev & 1 & 13 \\
\hline & 3 & & brigadir Anton Turk & 6 mesecev & 1 & 15 \\
\hline & 4 & \multirow{2}{*}{$\begin{array}{l}\text { generalmajor } \\
\text { Ladislav Lipič }\end{array}$} & brigadir Bogdan Beltram ${ }^{9}$ & $\begin{array}{c}3 \text { leta } \\
\text { in } 10 \text { mesecev }\end{array}$ & 7 & 18 \\
\hline & 5 & & major Evgen Primožič & 5 mesecev & 1 & 13 \\
\hline & 6 & $\begin{array}{l}\text { generalpodpolkovnik } \\
\text { Albin Gutman }\end{array}$ & \multirow{2}{*}{$\begin{array}{l}\text { podpolkovnik } \\
\text { Evgen Primožič }\end{array}$} & $\begin{array}{c}1 \text { leto } \\
\text { in } 8 \text { mesecev }\end{array}$ & 7 & 14 \\
\hline & 7 & $\begin{array}{l}\text { generalmajor } \\
\text { mag. Alojz Šteiner }\end{array}$ & & $\begin{array}{l}8 \text { mesecev } \\
\text { (do 10/'08) }\end{array}$ & 3 & 10 \\
\hline & \multicolumn{4}{|c|}{ Skupaj: } & 23 & $97^{10}$ \\
\hline
\end{tabular}

Prva številka Biltena SV je izšla novembra 1999. Do oktobra 2008 je bilo izdanih 23 številk, od tega 7 tematskih. Objavljenih je bilo 194 prispevkov na skoraj 3500 straneh. Ugotovimo, da je bilo v prvih sedmih letih izdanih 12 številk in objavljenih 95 prispevkov ali 48 odstotkov vseh. V zadnjih treh letih se je intenzivnost povečala, saj je bilo izdanih 11 številk s skupaj 109 prispevki ali 52 odstotki vseh. Povečanje števila izdaj je posledica uredniške politike, da se na leto oblikujejo po štiri številke,

${ }^{6}$ Kvantitativni del analize je opravil mag. Uroš Trinko iz GŠSV, za kar se mu zahvaljujem.

Upoštevano obdobje delovanja uredniškega odbora od septembra 1999 do oktobra 2008.

${ }_{8}$ Izdajanje Biltena SV se je začelo v obdobju načelnikovanja generalpodpolkovnika Iztoka Podbregarja, ki je odobril zamisel zanj in podpiral izdajanje. Mag. Iztok Podbregar je leta 2000 dosegel doktorski naziv.

9 Brigadir Bogdan Beltram je bil edini odgovorni urednik Biltena, ki se je do sedaj kot svetovalec načelnika Ğ́ ukvarjal predvsem z urednikovanjem, drugi odgovorni uredniki so kot prednostne opravljali druge naloge $v S V$.

${ }^{10}$ V sestavi uredniških odborov je bilo do zdaj 18 žensk, od tega 17 iz MO, ena pa ni zaposlena v obrambnem sistemu. 
med katerimi so tudi tematske. S tematskimi izdajami se poskušajo celoviteje in interdisciplinarno obdelati posamezna vprašanja ali tematska področja, ki so bila pred tem obravnavana na konferencah ali simpozijih v MO. Tako je bila tretja številka v osmem letniku (skrajšano 8/Št. 3) namenjena vprašanjem upravljanja znanja na MO, številka 8/Št. 4 pa ugotovitvam iz raziskave Človeški dejavnik v vojaškem sistemu. Številki 9/Št. 2 in 10/Št. 3 obravnavata protiterorizem, številka 9/ Št. 3 krizno upravljanje, številka 10/Št. 1 izobraževanje častnikov SV v prihodnosti ter številka 10/Št. 2 obvladovanje stresa v SV. V tabeli 2 je prikazana dinamika izdaj v posameznih letih, vključno do številke 10/Št. 3.

\begin{tabular}{|c|c|c|c|c|c|c|}
\hline \multirow{12}{*}{$\begin{array}{r}\text { Tabela 2: } \\
\text { Pregled številk } \\
\text { in prispevkov } \\
\text { Biltena SV po } \\
\text { letnikih od } 1999 \\
\text { do } 2008\end{array}$} & Letnik & $\begin{array}{l}\text { Številke v } \\
\text { letniku }\end{array}$ & $\begin{array}{l}\text { Število } \\
\text { tematskih } \\
\text { izdaj }\end{array}$ & $\begin{array}{c}\text { Število } \\
\text { navadnih } \\
\text { izdaj }\end{array}$ & $\begin{array}{c}\text { Število } \\
\text { prispevkov }\end{array}$ & Število strani \\
\hline & 1 (1999) & 1 & & 1 & 10 & 125 \\
\hline & $2(2000)$ & 2 & & 2 & 16 & 152 \\
\hline & $3(2001)$ & 2 & & 2 & 11 & 217 \\
\hline & $4(2002)$ & 2 & & 2 & 11 & 272 \\
\hline & $5(2003)$ & 2 & & 2 & 18 & 314 \\
\hline & 6 (2004) & 1 & & 1 & 6 & 180 \\
\hline & 7 (2005) & 2 & & 2 & 13 & 276 \\
\hline & $8(2006)$ & 4 & 2 & 2 & 39 & 718 \\
\hline & 9 (2007) & 4 & 2 & 2 & 32 & 672 \\
\hline & $10(2008)$ & 3 & 3 & & 38 & 567 \\
\hline & Skupaj & 23 & 7 & 16 & 194 & 3493 \\
\hline
\end{tabular}

Zanimiv je vpogled v strukturo objavljenih prispevkov, ki potrjuje, da je Bilten SV tipična vojaškostrokovna publikacija. V desetih letih obravnava vojsko 131 člankov od 194, kar je 68 odstotkov, medtem ko obrambne zadeve brez vojske obravnava 54 člankov ali 28 odstotkov, preostalih 9 prispevkov so uvodniki, ki smo jih uvrstili v kategorijo drugo. Zanimivo je, da je leta 2004, ko je Republika Slovenija vstopila v zvezo Nato in se pridružila EU, izšla le ena številka s 6 članki. Od leta 2006 so bile vse številke pospremljene $\mathrm{v}$ javnost z uvodnikom, bodisi načelnika Generalštaba bodisi odgovornega urednika, v zadnjem letu pa tudi tako imenovanega gostujočega urednika. Na grafu 1 je prikazano razmerje med članki o vojaških zadevah ter članki o širših obrambnih zadevah, in sicer je struktura objavljenih prispevkov glede na število strani v razmerju $65: 34$, izraženo v odstotkih. 

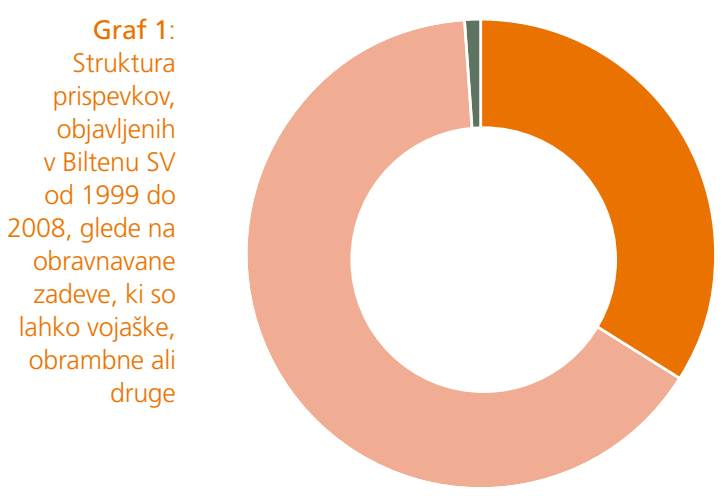

Obrambne zadeve $34 \%$

Vojaške zadeve $65 \%$

Drugo $1 \%$

Vsebinska analiza člankov pokaže, da se znotraj vojaških zadev pojavlja dvanajst področij. Pri tem so bile največkrat obravnavane vsebine protiterorizma s 23 članki ali devetimi odstotki ter izobraževanja in usposabljanja z 22 članki ali 11 odstotki, sledijo pa psihološka dejavnost (18 člankov, 7 odstotkov), kadrovsko področje (17 člankov, 9 odstotkov) ter operativno področje in štabno delo (13 člankov, 8 odstotkov). Pri obrambnih zadevah je bilo objavljenih največ člankov z vsebinami o teoriji organizacije in menedžmenta, in sicer kar 28, kar je 14 odstotkov, ter obrambne politike (10 člankov, 4 odstotki). Pregled člankov po strukturi je predstavljen v tabeli 3. Natančen pogled v strukturo člankov po področjih potrjuje trditev, da je po prenehanju izhajanja Vojstva njegovo vlogo prevzel Bilten SV. Razveseljuje podatek o številu objav o dveh najbolj aktualnih temah zadnjega časa, to je terorizmu in protiteroizmu ter o organizaciji vojaškega izobraževanja za SV. Manj razveseljiva je ugotovitev, da je bil s področja nabavne logistike v desetih letih objavljen le en članek in da ni bilo nobenega članka o Evropski obrambni agenciji (European Defence Agency - EDA) ali o kartografiji in podpori GIS (geografski informacijski sistemi). Prav tako v Biltenu SV do zdaj ni bilo objavljenih člankov o demokratičnem nadzoru nad oboroženimi silami, o podobi vojske v javnosti ali podpori vojske v nalogah zaščite in reševanja. Zapisano kaže na pomanjkljivostno nišo. 
Tabela 3:

Struktura

člankov,

objavljenih v

Biltenu SV, glede na področje $e^{11}$

\begin{tabular}{|c|c|c|c|c|}
\hline Vrsta zadev & Področje & $\begin{array}{l}\text { Število } \\
\text { člankov }\end{array}$ & $\begin{array}{l}\text { Število } \\
\text { strani }\end{array}$ & Odstotki \\
\hline \multirow{12}{*}{ Vojaške zadeve } & kadrovsko področje & 17 & 328 & 9 \\
\hline & obveščevalno področje & 4 & 91 & 3 \\
\hline & operativno področje in štabno delo & 13 & 282 & 8 \\
\hline & izobraževanje in usposabljanje & 22 & 369 & 11 \\
\hline & logistično področje & 9 & 189 & 5 \\
\hline & področje C4I & 5 & 136 & 4 \\
\hline & civilno-vojaško sodelovanje & 3 & 39 & 1 \\
\hline & Nato in EU & 4 & 26 & 1 \\
\hline & operacije & 3 & 31 & 1 \\
\hline & voditeljstvo in etika & 10 & 184 & 5 \\
\hline & protiterorizem & 23 & 330 & 9 \\
\hline & psihološka dejavnost in stres v SV & 18 & 257 & 7 \\
\hline \multirow{8}{*}{ Obrambne zadeve } & obrambna politika & 10 & 157 & 4 \\
\hline & vključevanje v Nato in EU & 4 & 87 & 2 \\
\hline & obrambno načrtovanje & 9 & 410 & 12 \\
\hline & MVS in obrambna diplomacija & 2 & 41 & 1 \\
\hline & teorija (organizacije, menedžmenta idr.) & 28 & 483 & 14 \\
\hline & nabavna logistika & 1 & 26 & 1 \\
\hline & Evropska obrambna agencija (EDA) & 0 & 0 & 0 \\
\hline & kartografija in GIS & 0 & 0 & 0 \\
\hline Drugo & uvodniki ${ }^{12}$ & 9 & 27 & 1 \\
\hline Skupaj & & 194 & 3493 & \\
\hline
\end{tabular}

Kakovost in strokovnost publikacije na zanimiv način kažejo tudi njeni avtorji in njihovo število. Seveda bi za podrobno proučitev tega potrebovali bistveno več podatkov, do katerih se s preprosto analizo člankov ni dalo priti. Pridobivanje podatkov o izobrazbi, činih in strokovnih ter akademskih nazivih avtorjev ne nazadnje niti ni bil naš cilj. V tem delu analize nas je predvsem zanimalo, iz katerega dela obrambne strukture prihajajo avtorji in kakšna je frekvenca pisanja po avtorjih. Ugotovimo, da so avtorji člankov do leta 2004 predvsem posamezniki, nato pa se pojavljajo tudi članki z dvema avtorjema ali več. Povedano drugače, pri 194 prispevkih je v desetih letih sodelovalo 237 avtorjev $^{13}$. Pri 166 prispevkih ali 86 odstotkih je bil avtor en

${ }^{11}$ Določitev področij znotraj vojaških in obrambnih zadev je izvedena po štabnih funkcijah $v$ vojski ter $v$ kombinaciji s funkcijskimi področji ali projekti v SV oziroma MORS.

12 Uvodniki praviloma ne izpolnjujejo vseh metodoloških zahtev kot članki, zato jih označujemo s prispevki. V tem pregledu smo jih zajeli zgolj zaradi celovitosti prikaza obsega izdaj.

13 Število vseh sodelujočih je seštevek samostojnih avtorjev in soavtorjev po člankih. Vseh je 155, od tega 30 žensk, vključno z 12 častnicami oz. višjimi vojaškimi uslužbenkami. 
sam, pri preostalih 28 člankih pa je sodelovalo skupaj 71 piscev. Dobri dve tretjini ali 69 odstotkov jih prihaja iz MO in SV, preostalih 31 odstotkov pa je zunanjih. Iz tabele 4 ugotovimo tudi, da je delež avtorjev iz tujine sorazmerno majhen, le triodstoten. Tuji avtorji se pojavljajo v zadnjih dveh letih in pišejo o terorizmu in protiterorizmu. Delež slovenskih avtorjev, ki niso iz MO in SV, pa se v zadnjih treh letih povečuje, kar kaže na to, da se Bilten SV vendarle prebija v širšo strokovno javnost. Krog piscev se v devetem (2007) in desetem letniku (2008) približuje številu 50, kar je zelo spodbudno. Če smo prej zapisali, da so pisci člankov za Bilten SV pretežno samostojni avtorji, podatki iz naslednje tabele kažejo, da stopnja sodelovanja pri nastajanju člankov vendarle ni tako slaba. Snovanje skupnih člankov je tako lahko dobra podlaga za spodbujanje skupinskega, zlasti vojaškostrokovnega in znanstvenoraziskovalnega dela. Člani uredniških odborov poudarjajo, da je bil v preteklosti ključni izziv v pridobivanju avtorjev in širjenju kroga sodelujočih ter $\mathrm{v}$ preseganju strahu pred strokovnim in še bolj znanstvenim pisanjem. Preseganje tega je bilo velikokrat močnejše od želje po publiciranju znanja in praktičnih izkušenj. Uredništva so si posebej prizadevala za širjenje vedenja o metodologiji in slogu pisanja strokovnih ter drugih člankov. V ta namen je bilo izdelanih več napotkov za pisanje in celo Navodilo za izdelavo Biltena $\mathrm{SV}^{14}$.

\begin{tabular}{|c|c|c|c|c|c|c|c|}
\hline \multirow{14}{*}{$\begin{array}{r}\text { Tabela 4: } \\
\text { Struktura } \\
\text { avtorjev } \\
\text { prispevkov V } \\
\text { Biltenu SV }\end{array}$} & Letnik & $\begin{array}{c}\text { Število } \\
\text { prispevkov }\end{array}$ & $\begin{array}{l}\text { Skupaj } \\
\text { avtorjev }\end{array}$ & \multicolumn{2}{|c|}{ Avtorji iz MO } & \multicolumn{2}{|c|}{ Drugi avtorji } \\
\hline & & & & SV & Drugi & Domači & Tuji \\
\hline & 1 (1999) & 10 & 10 & 10 & 0 & 0 & 0 \\
\hline & $2(2000)$ & 16 & 17 & 17 & 0 & 0 & 0 \\
\hline & $3(2001)$ & 11 & 13 & 12 & 0 & 1 & 0 \\
\hline & $4(2002)$ & 11 & 12 & 11 & 0 & 1 & 0 \\
\hline & $5(2003)$ & 18 & 20 & 19 & 1 & 0 & 0 \\
\hline & $6(2004)$ & 6 & 6 & 6 & 0 & 0 & 0 \\
\hline & $7(2005)$ & 13 & 17 & 17 & 0 & 0 & 0 \\
\hline & $8(2006)$ & 39 & 47 & 20 & 6 & 21 & 0 \\
\hline & $9(2007)$ & 32 & 45 & 26 & 1 & 14 & 4 \\
\hline & $10(2008)$ & 38 & 50 & 16 & 0 & 31 & 3 \\
\hline & Skupaj & 194 & $237^{15}$ & 154 & 9 & 67 & 7 \\
\hline & \multicolumn{3}{|c|}{ Odstotki glede na vse avtorje } & 65 & 3,8 & 28,2 & 3,0 \\
\hline
\end{tabular}

\footnotetext{
${ }_{14}$ Avtor Navodila za izdelavo Biltena Slovenske vojske, ki je bilo izdano leta 1999, je podpolkovnik Evgen Primožič, sedanji odgovorni urednik. Navodilo je preklicano z izdajo novega Navodila za pripravo in izdajo periodičnih publikacij št. 0070-4, ki ga je 7. 5. 2007 podpisal minister za obrambo.

${ }_{15}$ Da bi se izognili nesporazumu, poudarjamo, da je v desetih letih pri 194 prispevkih sodelovalo 155 avtorjev.
} 
Višji vojaški uslužbenec dr. Denis Čaleta je avtor z največ objavljenimi članki (9), prav tako je avtor z največ članki, ki prihaja iz SV, iz upravnega dela MO je to mag. Robert Masten (3 članki), zunanja avtorica z največ članki (4) pa je prof. dr. Ljubica Jelušič. V tabeli 5 je prikazan pregled avtorjev po številu prispevkov ne glede na to, ali so bili samostojni ali se pojavljajo kot soavtorji. Ugotovimo, da je 114 avtorjev objavilo po en prispevek, preostalih 41 sodelavcev pa se pojavlja z dvema ali več prispevki.

Tabela 5: Pregled avtorjev glede na število objavljenih prispevkov od 1999 do 2008

\begin{tabular}{|l|l|l|l|l|l|l|l|}
\hline \multirow{2}{*}{$\begin{array}{l}\text { Število vseh } \\
\text { člankov }\end{array}$} & \multirow{2}{*}{$\begin{array}{l}\text { Število vseh } \\
\text { avtorjev }\end{array}$} & \multicolumn{5}{|c|}{ Število avtorjev glede na število objavljenih prispevkov } \\
\cline { 3 - 10 } & & 1 & 2 & 3 & 4 & 5 & več kot 5 \\
\hline 194 & 155 & 114 & 25 & 6 & 4 & 3 & 3 \\
\hline
\end{tabular}

Seveda analiza ne bi bila popolna, če ne bi vsaj delno predstavili še naklade in stroškovnega vidika izhajanja ${ }^{16}$. Leta 2006 je bila naklada 400 izvodov, strošek tiskanja na številko pa je bil 2,49 evra, tako da so bili skupni letni stroški 3990 evrov. Leta 2007 je bila naklada 470 izvodov, pri čemer je bil strošek na številko od 3,61 do 4,33 evra, za tri številke pa so bili stroški 5595 evrov. ${ }^{17}$ Naklada za izdane tri številke leta 2008 je bila 500 izvodov, pri čemer je strošek na številko od 3,32 do 5,39 evra, tako da so bili dosedanji letošnji stroški 6170 evrov. Predstavljena analiza izhajanja Biltena SV v preteklih desetih letih kaže, da se je publikacija uveljavila kot strokovno glasilo Slovenske vojske. Nekatere začetne težave in uresničeni ter še nedoseženi izzivi so razvidni tudi iz prikazanih statistik. Statistike pa ne morejo prikazati volje in volonterstva $\mathrm{v}$ pozitivnem pomenu besed, ki so ju v pripravo številk vlagali odgovorni uredniki in člani uredniških odborov. Ti so kljub temu, da so vanje bili imenovani z ukazi, to opravljali z veliko dobre volje in entuziazma. Zato čutim dolžnost za zahvalo vsem, ki so sooblikovali Bilten, še posebej tistim, ki so si prizadevali, da je preživel, se ohranil in v zadnjih letih dvignil »naklado« ter se usmeril tja, kamor kot podobne publikacije drugih držav v zavezništvu spada. »Znanje zmaguje« je slogan Biltena SV, ki je gotovo aktualen tudi za naprej. Toliko bolj, ker sta znanje in strokovnost temeljni odliki sodobnega vojaškega profesionalca in spreminjanja vojsk. Zapišimo drugače: Vojska, ki svojega znanja ne zna publicirati, ga težko uveljavi tudi v praksi. Tako je jasnejše spoznanje, da je treba po desetih letih izhajanja Biltena SV še pogumneje stopati naprej.

\section{UREDNIŠKA POLITIKA - STRATEGIJA LETA 2008}

7. novembra 2007 se je na pogovor pri meni najavil odgovorni urednik uredniškega odbora Biltena SV in me seznanil z določilom Navodila za pripravo in izdajanje

\footnotetext{
${ }^{16}$ Podatki o finančnih izdatkih za Bilten SV pred letom 2006 niso bili dosegljivi.

${ }_{17}$ Bilten SV 9-4 (2007) je bil natisnjen leta 2008, zato stroški niso vključeni za leto 2007.
} 
periodičnih publikacij Slovenske vojske, po katerem sem po funkciji določen za glavnega urednika Biltena SV, ter z odločitvijo načelnika GŠSV, da se oblikuje novo »uredništvo«. Seznanitev s stanjem in načinom delovanja uredniškega odbora, nekaterimi dosežki, pa tudi težavami, je kazala na to, da gre za nov izziv, ki se ga je treba lotiti z vso resnostjo. Odgovornemu uredniku sem, tako kot on pred tem meni, naložil vrsto nalog, ki so bile povezane z oblikovanjem in začetkom delovanja novega uredniškega odbora, in sicer od poročila o delovanju v preteklem obdobju do idej za nov program dela, poslovnik in seveda novo sestavo ekipe, ki bo, še vedno predvsem na prostovoljni podlagi, reševala številna vprašanja ob izhajanju te publikacije. Reševanje dodeljenih nalog in podrobnejše seznanjanje z razmerami je trajalo kar nekaj časa. V vmesnem obdobju je bil opravljen tudi obisk v Službi za založništvo MO, poleg tega smo ugotovili, kako potekata načrtovanje in organizacijska podpora v pristojni notranji organizacijski enoti za založništvo in izdajateljstvo PDRIU. 11. februarja 2008 je bil s sklepom načelnika Generalštaba Slovenske vojske imenovan nov uredniški odbor, 20. februarja pa je bila opravljena tudi primopredaja med prejšnjim in novim uredniškim odborom. Glede na to, da je bila v izdajateljskih ciljih za leto 2008 predvidena izdaja štirih številk, za pripravo in izdajo posamezne številke pa so ob zbranih prispevkih potrebni skoraj trije meseci, je razumljivo, da je bilo temu treba prilagoditi tudi uredniško vnemo in aktivnosti za doseganje postavljenih ciljev. Navedene ugotovitve in pripravljenost članov uredniškega odbora za konstruktivno reševanje ter timsko delo so premagali marsikatero oviro v službah in postopkih za pripravo in izdajo publikacij, ki jih vodijo pristojne organizacijske enote v MO. Ko smo se v uredniškem odboru začeli pogovarjati tudi o uresničevanju strategije, ki smo jo zapisali v Programu dela, je bilo sklenjeno, da jo glavni urednik predstavi v zadnji številki letnika 2008 (10/Št. 4), ko naj bi bil Bilten SV predstavljen javnosti tudi v novi grafični podobi. Uredniški odbor je glavna določila uredniške politike zapisal v Program dela uredniškega odbora Biltena SV, ki ga je sprejel na drugi seji 7. marca 2008. Zaradi nekaterih že navedenih nejasnosti pri nastajanju je v programu uredniška politika označena kot strategija. Tako si je uredniški odbor zastavil cilj »ostati uspešen, kakovosten in odprt za vse, ki želijo sodelovati pri pisanju prispevkov« (Program 2008: I/3. odst.). Povsem jasno je opredeljen temeljni cilj za leto 2008, ki je usmerjen v dvig klasifikacije publikacije skladno s habilitacijskimi merili Univerze v Ljubljani in Univerze v Mariboru, in sicer iz sedanje četrte skupine revij v tretjo. Pomembna je tudi usmeritev uredniškega odbora k razvoju vojaške stroke in vojaških znanosti z objavljanjem člankov, ki bodo na teh področjih predstavljali dodano vrednost sedanjim spoznanjem. Tem ciljem je bil prilagojen tudi akcijski načrt za leto 2008 (Program dela, 2008). Ta je na eni strani usmerjen v doseganje letošnjega cilja - izdajo štirih številk in tisk manjkajoče številke iz leta 2007, po drugi pa ima vrsto nalog, povezanih s prej omenjenimi cilji, ki jih bomo pojasnili v nadaljevanju. Lahko zapišemo, da je sedmi uredniški odbor Biltena SV v dosedanjem delu uspešno uresničil obe vrsti nalog. V ospredju so bile tiste, ki so zagotavljale izdajo načrtovanih številk v letošnjem letu. Na začetku je poseben izziv predstavljalo organiziranje uredniškega odbora. Skupno oblikovanje poslovnika in programa dela je vzelo precej časa, saj smo zanju porabili kar dve seji. Pozitivni učinki takšnega skupinskega pristopa pa so bili kmalu opazni, saj sedaj uredniški 
odbor deluje kot dobra in uigrana ekipa, v kateri ne manjka različnosti in kritičnosti. V poslovnik smo zapisali tudi nekaj o posebnostih vloge glavnega in odgovornega urednika, odločanju na sejah ter seveda številne procesne določbe.

V uredniškem odboru prisegamo na to, da je sodelovanje pri njegovem delu dobra priložnost za učenje. Tega je pri snovanju posameznih številk, zlasti tematskih, veliko. Če upoštevamo še reševanje recenzij in postopke selekcije prispevkov, lahko zapišemo, da tudi strokovnih izzivov pri delu uredništva ne manjka. Posamezni člani se preizkušajo kot »gostujoči uredniki«, to pomeni, da urejajo posamezne številke. Ko bodo dokončno uspešno razmejena opravila med odgovornim, gostujočim in tehničnim urednikom, bo stresnih situacij pri lovljenju načrtovanih rokov bistveno manj. Na tem področju je eden ključnih izzivov, ne le za uredniški odbor, temveč tudi širše, uveljavitev uspešne metodologije in postopkov pri ustvarjanju publikacije, pri katerih bo čim manj izgube časa in nepotrebnega birokratiziranja ali skrivanja za nefleksibilnimi postopki pristojnih organizacijskih enot, ki so zadolžene za podporo uredniškim odborom ${ }^{18}$.

Dosežki in napake so spremljevalci vsakega dela, tudi uredniškega. Zato je treba omeniti še problem in pridobljeno izkušnjo, s katero smo se srečali v uredniškem odboru ob odzivu in kritiki na prispevek, objavljen v četrti številki lanskega letnika $\left(9 /\right.$ Št. $\left.4^{19}\right)$. Avtorji smo seveda odgovorni za zapisano, s tem izražamo tudi svojo strokovno in jezikovno sposobnost. Pri omenjenem primeru pa smo ugotovili, da lahko avtorji z napačnim, metodološko neustreznim ali površnim navajanjem škodo povzročimo tudi tistim, ki jih navajamo. Primer je utrdil prepričanje, da je pri prihodnjem snovanju številk Biltena SV treba v celoti upoštevati zahteve recenzije in čas zanjo.

Izzivi, ki čakajo uredniški odbor Biltena SV do konca leta 2008, so povezani z načrtovanjem izdaje publikacij za leto 2009, pa tudi še z nedokončanimi organizacijskimi nalogami iz letošnjega programa. V mislih imamo načrtovano predlaganje sprememb in dopolnitev Navodila za pripravo in izdajanje periodičnih publikacij, uresničitev ideje za oblikovanje uredniškega sveta namesto razširjenega uredniškega odbora, sodelovanje z ustanovami in publikacijami v tujini ter ne nazadnje dokončno oblikovanje spletne strani $\mathrm{v}$ slovenskem in angleškem jeziku ter tovrstnega stika z bralstvom. Novi uredniški odbor je dobil pomembne izkušnje v pripravah vseh štirih letošnjih številk. Vsaka zase je bila svojstven preizkus organizacijske zrelosti uredništva. Še največ neznank se je pojavilo pri snovanju prve tematske številke, posvečene izobraževanju častnikov SV v prihodnosti, eni najbolj »vročih« tem, s strokovno ter organizacijsko najbolj različnimi pogledi. Strokovno še zahtevnejša je bila letošnja druga tematska številka, v kateri smo se soočili z vso nujnostjo recenzij pri tematiki obvladovanja stresa v SV. Škoda, ker nekaterih prispevkov

${ }_{18}$ Za takšen primer bi lahko označili tudi zaplete pri pripravi nove grafične podobe, kjer nismo uspeli premagati vseh ovir na poti do želenega cilja.

19 Več o tem v Polemike, odgovori in komentarji http://www.mors.si/index.php?id=223 1.10.08) ter v pripombah in popravkih ppk. Mojce Pešec http://www.mors.si/fileadmin/mors/pdf/Bilten_SV/Bilten_odgovor_Jun08.pdf 1.10.08) 
nismo prevedli ali jih celo napisali v tujem jeziku in tako še bolj odprli revije v mednarodno okolje. To nam je uspelo pri tretji tematski številki (10/Št. 3), posvečeni protiteroristični tematiki in prizadevanjem na tem področju v Jugovzhodni Evropi. S to tematsko številko Bilten SV dokončno vstopa v mednarodni prostor ${ }^{20}$. Kar nekaj novosti je bilo pri tem doseženih; poudarjam pristop, s katerim so sestavki prevedeni $\mathrm{v}$ angleški jezik. $\mathrm{S}$ tem je ta publikacija uspešno podpirala posebno konferenco o protiterorizmu, ki jo je že drugič organizirala Slovenija. Četrta številka, ki je posvečena deseti obletnici izhajanja, ima dodatno kakovost v izbranih prispevkih, saj sta temu gostujoča urednica in uredniški odbor namenila posebno pozornost. Pri tretji in četrti številki smo se srečali tudi s primeri, da so nekateri avtorji odstopili od objave, ker so bile zanje pripombe recenzentov »prehude «.

\section{VIZIJA, STRATEGIJA IN PRIHODNJI IZZIVI ZA BILTEN SV}

Vizija uredniškega odbora Biltena SV je doseči takšno raven kakovosti in prepoznavnosti člankov in publikacije, da bo Bilten uvrščen v tretjo skupino publikacij po habilitacijskih merilih Univerze v Ljubljani in Univerze v Mariboru, vsebine pa bodo prispevale $\mathrm{k}$ razvoju obrambno-vojaške znanosti oziroma stroke skladno z opredeljenimi potrebami izdajatelja. Pri doseganju vizije je kot pot do cilja pomembna strategija za njeno uresničitev. Naša strategija je izboljšanje kakovosti publikacije in s tem dvig ravni njene klasifikacije v tretjo skupino, kar je mogoče $\mathrm{z}$ racionalnim načrtovanjem, premišljeno izbiro vsebin in avtorjev, uvedbo recenzij in doslednim spoštovanjem anonimnega recenzentskega postopka. Načrtno organizacijsko in tehnično delo pri snovanju posameznih številk ter nadgradnja dela glavnega in tehničnega urednika oziroma uredništva kot celote so pomembni za uspeh, kar je potrdila tudi letošnja izkušnja. Pomemben izziv je tudi uveljavitev sodelovanja $\mathrm{z}$ domačimi in tujimi strokovnimi ter znanstvenimi organizacijami in povezava $\mathrm{z}$ njihovimi publikacijami. To omogoča objavljanje prispevkov tujih in gostujočih avtorjev, hkrati pa podpira možnosti za objavljanje prispevkov avtorjev iz SV ter MO v tujih publikacijah. V uredniškem odboru se zavedamo, da prehod publikacije $\mathrm{V}$ višjo klasifikacijsko skupino ni preprost in odvisen samo od dela uredništva, saj zahteva predstavitev znanja v prispevkih, strokovni in vedno bolj tudi znanstveni pristop k pisanju, uporabo ustreznega strokovnega jezika ter ne nazadnje spoštovanje raziskovalne metodologije pri oblikovanju prispevkov. $\mathrm{Z}$ navedenim lahko Bilten SV pomembno prispeva tudi k razvoju bodočih strokovnjakov in znanstvenikov v vojski ter na MO.

Vprašanje širjenja kroga sodelavcev je tesno povezano z dvigom kakovosti, čeprav je v navideznem nasprotju, ker se s širjenjem količine običajno zmanjšuje kakovost. Navedimo, da je trenutno v SV zaposlenih deset doktorjev znanosti, število magistrov pa bo kmalu večje od števila polkovnikov. Če k temu dodamo še potencial upravnega dela MO in zunanjih sodelavcev, se odpira vprašanje, s čim privabiti tiste, ki znajo, k ustvarjanju in sodelovanju v publikaciji. Profesionalna publikacija ima tudi nekaj

${ }^{20}$ Že tematska številka 9/Št. 2 o protiterorizmu iz leta 2007 je doživela zelo ugoden odziv, čeprav je bila izdana po konferenci, ki je bila na Igu pri Ljubljani septembra 2007, in posredovana na številne tuje naslove. 
povsem materialnih izzivov, povezanih s finančnim vrednotenjem člankov. Ker je v nekaterih publikacijah, ki jih izdaja MO, ta praksa že uveljavljena, lahko upamo, da jo bomo lahko uveljavili tudi v Biltenu SV. Ali je to pot za prehod publikacije iz volonterstva $\mathrm{v}$ profesionalizem, je vprašanje, ki ima svoje zagovornike, pa tudi nasprotnike.

Kljub »vojaški organiziranosti« uredniškega odbora Biltena v njegovem delovanju prisegamo na odprtost in konstruktivnost. To pa pomeni tudi odprtost za pobude iz ožjega in širšega okolja. Širjenje okolja Biltena SV pa zahteva zagotovitev dostopnosti prek spletne strani in začetek komuniciranja s strokovno javnostjo po internetu. Tu smo gotovo še na začetku, čeprav smo bili letos zelo veseli, da nam je uspelo za Bilten SV dobiti prostor na spletnih straneh MO (htpp://www.mors.si/index. php?id=213). Verjamemo, da bomo na tej podlagi uspeli v prihodnosti oblikovati in širiti tudi mrežo sodelavcev, najprej v Sloveniji in zatem še v mednarodnem okolju.

Poseben strokovni izziv za uredništvo in avtorje prispevkov je povezan z vprašanjem zagotavljanja ravnotežja med teorijo in prakso. Pogled in primerjave s podobnimi publikacijami v tujini zgovorno kažejo, da je pri takšnih publikacijah usmeritev v empiričnost primarna, pri čemer teoretične podlage služijo kot izhodišča ali podpora za preverjanje v praksi. Izdajatelja gotovo zanima predvsem praktična uporabnost publiciranega znanja in spoznanj. Lahko bi seveda sklepali tudi drugače, ker je Bilten SV opredeljen tudi kot informativna publikacija, namenjena izobraževanju. Pri veščinskem vojaškem učenju je praktični del seveda zelo pomemben, kar pa se spremeni pri splošnem vojaškostrokovnem izobraževanju, predvsem častnikov kot pripadnikov vojaške profesije.

Sklep Bilten SV je v desetih letih svojega izhajanja prehodil zanimivo pot volonterstva in vztrajnosti urednikov. Število publikacij in avtorjev se je postopno širilo ter v zadnjih treh letih doseglo zavidljivo raven. To kaže, da se je Bilten utrdil in postal pomemben vojaškostrokovni glasnik, ne le Slovenske vojske, temveč tudi širše. K temu je pomembno prispevalo odpiranje uredništva navzven in pridobivanje avtorjev iz tujine. Tak primer je bil v letih 2007 in 2008 povezan z mednarodno konferenco o protiterorizmu v Sloveniji in izidom posebnih tematskih številk. Tako je Bilten prestopil nacionalne okvire in presegel dilemo, ali pisati in objavljati zgolj v slovenskem jeziku oziroma ali so čas in okoliščine zreli za objavo člankov v jezikih gostujočih avtorjev. Sedmi uredniški odbor je zaznal in sprejel izzive, ki so pred naslednjim desetletjem publikacije. Ti izzivi so povezani z nadaljnjim odpiranjem publikacije v mednarodno okolje, prehodom na internetni medij, širjenjem kroga sodelujočih ter dvigom strokovnosti in s tem kakovosti Biltena SV. Upam, da bo Bilten po desetih letih dobil novo grafično podobo, in če bodo doseženi tudi drugi cilji, lahko pričakujemo, da ga bodo pripadniki SV in tudi strokovna javnost v MO ter širšem obrambnem okolju brali in uporabljali kot izziv za svoje razmišljanje ali kritiko. Z navedenim lahko dosežemo tudi glavni cilj, ta pa je uvrstitev publikacije $\mathrm{v}$ višji klasifikacijski rang. Z odpiranjem v širši prostor, dvigom kakovosti prispevkov, 
njihovim ustreznim vrednotenjem in nagrajevanjem pa bo odprta pot do strokovne tekmovalnosti ter z njo do ustvarjalne vrednosti za Slovensko vojsko in obrambni sistem. Tako smo prepričani, da ni več daleč čas, ko bo uredniški odbor lahko spremenil svojo vlogo iz iskalca in nabiralca prispevkov $\mathrm{v}$ izbiralca oziroma selektorja vojaškostrokovnih besedil glede na njihovo kakovost in pomen.

\section{Literatura}

1. Generalštab Slovenske vojske, 2008: Namen in vloga uredniškega odbora, Dostopno na http://www.mors.si/index.php?id=214 (1. 10. 2008).

2. Generalštab Slovenske vojske, 2008: Polemike, odgovori in komentarji. Dostopno na http://www.mors.si/index.php?id=223 (1. 10. 2008).

3. Generalštab Slovenske vojske, 2008: Poročilo o delu Uredniškega odbora Biltena SV v obdobju 2006-2007.

4. Generalštab Slovenske vojske, 2008: Sklep o imenovanju Uredniškega odbora Biltena Slovenske vojske.

5. Ministrstvo za obrambo, 2007: Navodilo za pripravo in izdajanje periodičnih publikacij Slovenske vojske. Dostopno na http://www.mors.si/fileadmin/mors/pdf/Bilten_SV/ Navodilo_pripravo_izdajanje_pubikacij_07_05_07.pdf(1. 10. 2008).

6. Ministrstvo za obrambo, 2007: Pravilnik o založniški in filmski dejavnosti v MO RS. Dokument MO, šifra 811-11-7/2005-34 z dne 24. 7. 2006.

7. Ministrstvo za obrambo, 1999: Navodilo za izdelavo Biltena Slovenske vojske. Dokument MO številka 017-04-21/98 z dne 17. 3. 1999.

8. Uroš TRINKO, Alojz ŠTEINER, 2008: Analiza Biltenov SV 1999-2008.

9. Uredniški odbor Biltena SV, 2008: Poslovnik uredniškega odbora za pripravo in izdajo Biltena Slovenske vojske. Dostopno na http://www.mors.si/fileadmin/mors/pdf/Bilten_SVI poslovnik_uredn_odbora.pdf(1.10.2008).

10. Uredniški odbor Biltena SV, 2008: Program dela uredniškega odbora Biltena SV. Dostopno na http://www.mors.si/fileadmin/mors/pdf/Bilten_SV/nacrt_dela_ urednistva_08.pdf (1.10.2008). 